Alignment: Journal of Administration and Educational Management

Volume 2, Nomor 2, Desember 2019

e-ISSN : 2598-5159

p-ISSN : 2598-0742

DOI : https://doi.org/10.31539/alignment.v2i2.1013

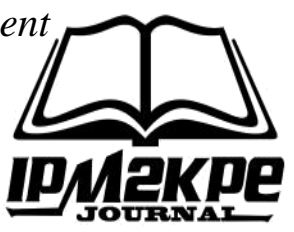

\title{
MANAJEMEN KELAS DI SMA NEGERI 2 MODEL KOTA LUBUKLINGGAU
}

\author{
Marianita $^{1}$, M. Rusni Eka Putra ${ }^{2}$, Ahmad Gawdy Prananosa ${ }^{3}$ \\ STKIP PGRI Lubuklinggau ${ }^{1,2,3}$ \\ Marianita2019@gmail.com ${ }^{1}$
}

\begin{abstract}
ABSTRAK
Tujuan penelitian ini adalah untuk mengetahui pengelolaan kelas di SMA Negeri 2 Model Kota Lubuklinggau. Penelitian ini menggunakan pendekatan kualitatif dengan metode deskiriftif kualitatif. Teknik pengumpulan data meliputi; observasi, wawancara dan dokumentasi. Untuk menetapkan keabsahan (trustworthiness) data diperlukan teknik pemeriksaan. Ada empat kreteria yang dapat digunakan untuk menguji keabsahan data, yaitu derajat kepercayaan (credibility), keteralihan (transferability), ketergantungan (dependability) dan kepastian akan data dan hasil penelitian, teknik analisi data menggunakan teknik; editing, kategori, mendisplay data dan penafsiran. Simpulan, pengelolaan kelas di SMA Negeri 2 Model Kota Lubuklinggau cukup baik, hal ini dapat dilihat dari suasana kelas dan motivasi siswa dalam belajar cukup baik dan kemudian juga dukungan fasilitas cukup memadai dalam pengelolaan manajemen kelas. Kemudian komunikasi antara teman sejawat dan pimpinan sekolah berjalan dengan baik dalam pengelolaan kelas, sehingga proses belajar dan mengajar di dalam kelas cukup kondusif
\end{abstract}

Kata Kunci; Manajemen Kelas, Sekolah Model

\begin{abstract}
The purpose of this study was to determine classroom management in the SMA Negeri 2 Model Lubuklinggau City. This study uses a qualitative approach with qualitative descriptive methods. Data collection techniques include; observation, interview and documentation. To determine the validity (trustworthiness) of the data required inspection techniques. There are four criteria that can be used to test the validity of data, namely the degree of trust (credibility), transferability, dependability and the certainty of data and research results, data analysis techniques using techniques; editing, category, displaying data and interpretation. Conclusion, classroom management in Lubuklinggau City Model 2 Senior High School is quite good, this can be seen from the classroom atmosphere and students' motivation in learning quite well and then also adequate facility support in managing classroom management. Then the communication between colleagues and school leaders runs well in classroom management, so the learning and teaching process in the classroom is quite conducive
\end{abstract}

Keywords; Classroom Management, Model Schools 


\section{PENDAHULUAN}

Keberhasilan siswa dalam belajar sangat ditentukan oleh strategi pembelajaran yang dilakukan oleh guru. Guru dituntut untuk memahami komponen-komponen dasar dalam melaksanakan kegiatan pembelajaran di dalam kelas. Oleh karena itu guru dituntut untuk paham tentang filosofis dari mengajar dan belajar itu sendiri. Mengajar tidak hanya sekedar mentransfer ilmu pengetahuan, akan tetapi juga sejumlah perilaku yang akan menjadi kepemilikan siswa.

Pengaturan metode, strategi, dan kelengkapan dalam pengajaran adalah bagian dari kegiatan manajemen pembelajaran yang harus dilakukan oleh guru. Untuk mewujudkan manajemen kelas di Sekolah Dasar, lingkungan fisik yang menguntungkan dan memenuhi syarat akan mendukung meningkatnya intensitas pembelajaran siswa dan mempunyai pengaruh positif terhadap pencapaian tujuan pengajaran. Manajemen kelas di Sekolah Dasar tidak hanya pengaturan belajar, fasilitas fisik dan rutinitas, tetapi menyiapkan kondisi kelas dan lingkungan sekolah agar tercipta kenyamanan dan suasana belajar yang efektif.

Dengan kreatifitas, pengalaman, latar belakang pendidikan guru dan kemampuan guru, maka akan berdampak pada kemampuan guru dalam mengelola kelas dengan baik, hasil penelitian Helsa dan Hendriati (2017) menjelaskan partisipan yang memiliki latar belakang pendidikan guru dan pengalaman kerja yang memadai memiliki kemampuan manajemen kelas yang baik. Sedangkan hasil penelitian Kartiningsih, Asrori, dan Syukri (2014) menjelaskan indikator fungsi manajemen kelas unggulan berupa perencanaan, pengorganisasian, penempatan gurudan pegawai, pendelegasian Kepala Madrasah, Koordinasi Kepala Madrasah, Guru, Pegawai dan Komite, pendanaan, evaluasi program kelas unggulan

Tugas dan peran guru sebagai pendidik profesional sesungguhnya sangat kompleks,tidak terbatas dalam perencanaan pembelajaran yang menyangkut merumuskan tujuan pembelajaran, materi pembelajaran menetapkan metode pembelajaran, media pembelajaran dan evaluasi untuk mengetahui hasil pembelajaran. Namun guru juga harus bisa memainkan perannya dalam pengelolaan kelas, baik yang menyangkut kegiatan mengatur tata ruang kelasyang merupakan; mengatur meja, tempat duduk siswa, menempatka papan tulis, maupunmenciptakan iklim belajar mengajar yang serasi dengan mengarahkan tingkah laku anak didik agar tidak merusak suasana kelas.

Suasana kelas yang kondusif merupakan merupakan modal penting untuk menciptakan kejernihan berpikir untuk mengikuti proses belajar mengajar. Oleh karena itu pengelolaan sekolah perlu menciptakan suasana gembira di sekolah yaitu suasana kekeluargaan yang akrab, dengan demikian guru termotivasi untuk mengelola kelas dengan baik, karena dengan pengelolaan kelas yang baikakan mempertinggi perkembangan mental dan sosial murid, dan memberi kebebasan 
intelektual dan pasih dalam karakter yang ditentukan, dan membuat suasana yang hangat antara guru dan murid yang memungkinkan pencapaian tujuan terlaksana.

\section{METODE PENELITIAN}

Penelitian ini menggunakan pendekatan kualitatif dengan metode deskiriftif kualitatif. Teknik pengumpulan data meliputi; observasi, wawancara dan dokumentasi. Untuk menetapkan keabsahan (trustworthiness) data diperlukan teknik pemeriksaan. Ada empat kreteria yang dapat digunakan untuk menguji keabsahan data, yaitu derajat kepercayaan (credibility), keteralihan (transferability), ketergantungan (dependability) dan kepastian akan data dan hasil penelitian. Disamping itu juga dilakukan triangulasi. Trianggulasi yaitu pemeriksaan silang dari berbagai sumber yang digunakan. Triangulasi yang banyak digunakan adalah triangulasi dengan sumber yaitu membandingkan dan mengecek balik derajat kepercayaan suatu informasi yang diperoleh melalui waktu dan alat yang berbeda dalam penelitian. teknik analisi data menggunakan teknik; editing, kategori, mendisplay data dan penafsiran .

\section{HASIL DAN PEMBAHASAN}

\section{Program dalam Meningkatkan Pengelolalan Kelas}

Kelas tentunya perlu dikelola dengan baik, agar dalam proses belajar dan mengajar dapat terlaksana dengan baik, agar proses pelaksanaan pembelajaran terlaksana dengan baik, maka perlu dibuat program untuk mengelola kelas dengan baik. Hasil wawancara dengan salah seorang guru adalah sebagai berikut:

"Memang benar dalam melaksanakan proses pembelajaran dengan baik, tentunya sangatlah membutuhkan pengelolaan kelas yang baik pula, maka dari itu saya membuat program agar pengelolaan kelas dapat terlaksan dengan baik"

Memang sangatlah diperlukan program yang jelas dalam mengelola kelas, sebab kelas merupakan pendukung dalam terlaksananya proses pembelajaran yang baik di kelas, hal ini sangatlah penting bagi guru dalam membuat program kelas yang baik, agar proses belajar dan mengajar dalam kelas dapat menyenangkan. Hasil wawancara dengan kepala sekolah, yakni sebagai berikut:

"Saya sangat menghimbau bagi guru untuk dapat mengelola kelas dengan baik, agar dalam pelaksanan belajar dan mengajar di dalam kelas dapat terlaksana dengan baik pula, sehingga guru perlu merancang program dalam mengelola kelas yang baik"

Memang guru harus membuat program agar dalam pengelolaan kelas dapat terlaksana dengan baik, seperti membuat jadwal kebersihan kelas, atau membuat variasi format tempat duduk siswa, agar tidak bosan dalam menerima pelajaran di dalam kelas. Hasil wawancara dengan salah seorang guru, yakni sebagai berikut: 
"saya sebagai guru selalu melakukan variasi dalam mengelola kelas, agar siswa tidak bosan dalam mengikuti pelajaran di dalam kelas, banyak program yang telah saya buat untuk mengelola kelas"

Memang sangatlah penting bagi guru untuk membuat program dalam mengelola kelas, agar dalam pelaksanaan pembelajaran dapa terlaksana dengan baik, dengan program yang baik, maka pengelolaan kelas dapat terlaksana dengan baik pula.

\section{Mengikuti Seminar atau Workshop dalam Pengelolaan Kelas}

Untuk meningktkan keahlian dalam pengelolaan kelas, tentunya sangatlah diperlukan pelatihan atau seminar dalam pengelolaan kelas, hal ini sebagai upaya untuk meningkatkan kompetensi guru dalam mengelola kelas, sehingga diharapkan guru dapat mengelola kelas dengan baik. Hasil wawancara dengan salah seorang guru, yakni sebagai berikut:

"Iya saya sering kali mengikuti pelatihan ataupun seminar dalam pengelolaan

kelas, agar saya mendapatkan ilmu yang up to date dalam pengelolaan kelas, sehingga dengan pengelolaan kelsa yang baik dapat menunjang proses pembelajaran yang baik pula"

Memang betul sangatlah penting bagi guru untuk mendapatkan pelatihan dalam pengelolaan kelas yang baik, sebab dengan guru mengikuti pelatihan pengelolaan kelas, maka skill dan kemampuan guru dalam mengelola kelas dapat terlaksana dengan baik pulan. Namun jika guru tidak pernah update ilmu tentang pengelolaan kelas, maka rasanya sulit bagi guru untuk mengelola kelas dengan baik. Hasil wawancara dengan kepala sekolah, yakni sebagai berikut:

"Saya sangat menyarankan bagi guru untuk mengelola kelas dengan baik, sebab hal ini penting terutama dalam proses pembelajaran di dalam kelas, maka dari itu saya sangat mendukung jika guru dapat mengikuti kegiatan pelatihan dalam pengelolaan kelas"

Sangatlah penting bagi guru dalam meningkatkan skil dan kemampuanya dalam mengelola kelas, sebab dengan kemampuan guru yang baik dalam mengelola kelas, maka dapat berdampak positif dalam proses pembelajaran di dalam kelas, namun sebaliknya jika guru tidak mampu mengelola kelas dengan baik, maka proses pebembelajaran di dalam kelas kurang dapat berjalan dengan baik pula.

\section{Urgensi Pengelolaan Kelas}

Dengan pengelolaan kelas yang baik dapat berdampak positif terhadap pembelajaran yang baik pula, sebab dengan pengelolaan kelas yang baik siswa dan guru akan merasa nyaman dalam berinteraksi selama proses pembelajaran 
berlangsung, sehingga mereka dapat saling berkomunikasi dan interaksi dengan baik sehingga proses pembelajaran di dalam kelas dapat terlaksana dengan baik pula. Hasil wawancara dengan salah seorang guru, yakni sebagai berikut:

"Sangatlah penting bagi kami sebagai guru dalam mengelola kelas dengan baik, sebab hal ini sangatlah mendukung dalam proses pembalajaran di dalam kelas, jika kelas tidak dikelola dengan baik, maka siswa akan merasa kurang nyaman dalam proses belajar dan mengajar di dalam kelas"

Sangatlah penting bagi guru dalam mengelola kelas dengan baik, sebabab di dalam kelas siswa dan guru berinteraksi, jika kelas tidak deikelola dengan baik, maka siswa akan merasa bosan dan begitu juga guru akan mengalami kesulitan dalam memberikan mata pelajaran kepada siswa dan siswa juga akan mengalami kesulitan dalam menerima materi pelajaran. Hasil wawancara dengan kepala sekolah, yakni sebagai berikut:

"Sangatlah penting bagi guru untuk melakukan pengelolaan kelas dengan baik, sebab ini akan membuat kelas manjadi nyaman, sehingga siswa akan merasa dengan mudah untuk menerima materi pembelajaran dari gurunya"

Pengelolaan kelas yang baik sangatlah membantu guru dalam melaksanakan tugasnya dengan baik pula, sebab kelas merupakan tempat dimana siswa dan guru berinteraksi, jika kelas yang didesain tidak dikelola dengan baik, maka akan menjadi hambatan bagi guru dan siswa dalam proses belajar dan mengajar, maka dari itu sangatlah penting sekali bagi guru untuk mengelola kelas dengan baik pula

\section{Penerapan pengelolaan kelas yang baik}

Pengelolaan kelas yang baik sangatlah penting bagi guru dalam meningkatkan motivasi dan semangat belajar siswa di dalam kelas. Siswa tentunya tidak ingin bosan dalam menerima pelajaran dari gurunya, namun jika suasana kelas dibuat senyaman mungkin, maka siswa akan mengalami kemudahna dan nyaman dalam proses belajar dan mengajar. Hasil wawancara dengan salah seorang guru, yakni sebagai berikut:

"Memang sangatlah penting untuk menciptakan suasana kelas yang nyaman dalam proses belajar dan mengajar di dalam kelas, dengan suasana nyaman, maka guru dan siswa kan menjadi semangat dalam proses belajar dan mengajar"

Penerapan pengelolaan kelas sangatlah penting dengan baik dan tepat, guru dalam mengelola kelas tentunya harus memperhatikan kondisi dan keadaan siswa, sebab siswa memiliki karakter dan kepribadian yang berbeda-beda, sehingga guru dapat mengetahui pola kelas seperti apa yang relevan dengan materi yang akan diajarkan. Hasil wawancara dengan salah seorang guru, yakni sebagai berikut: 
"Memang benar sangatlah penting bagi kami sebagai guru dalam menerapkan pengelolaan kelas memperhatikan kondisi obyek dalam hal ini siswa dengan materi yang akan disampaikan"

Pengelolaan kelas yang baik sangatlah membantu guru dalam kesuksesan proses belajar dan mengajar di dalam kelas. Siswa tentunya memiliki karakter dan kepribadian yang berbeda-beda dalam menrima pelajaran, sehingga sangat penting bagi guru dalam menerapkan manajemen kelas memperhatikan materi yang akan disampaikan, sehingga dalam penyampaian materi siswa dapat dengan mudah untuk menerima materi pelajaran yang disampaikan oleh guru di dalam kelas. Hasil wawancara dengan kepala sekolah yakni sebagai berikut:

"Memang benar guru harus menerapkan pengelolaan kelas yang tepat, agar dalam pelaksanaan pembelajaran pengelolaan kelas yang baik dapat mendukung proses pembelajaran yang baik pula"

Sangatlah penting dan relevan bagi guru dalam menerapkan pengelolaan kelas yang baik kepada siswa, sebab dengan pengelolaan kelas yang baik dapat meningkatkan prestasi belajar siswa yang baik pula, jika siswa kurang merasa nyaman di dalam kelas, maka akan berdampak buruk dalam hasil belajar siswa.

\section{Rata-Rata Kemampuan Siswa dalam Menerima Materi Pembelajaran di Dalam Kelas.}

Siswa mengalami kemudahan dalam menerima materi pembelajaran di dalam kelas sebab siswa merasakan kenyamanan dalam proses pembelajaran di dalam kelas, sehingga hal ini menuntut guru untuk senantiasa mengelola kelas dengan baik, agar siswa selalu termotivasi belajar dengan baik pula. Hasil wawancara dengan salah seorang siswa, yakni sebagai berikut:

"Saya merasa nyaman jika belajar dengan format kursi yang beragam, sehingga saya tidak bosan dalam menerima materi pembelajaran dari guru, dengan merasa nyaman di dalam kelas, maka kami lebih termotivasi untuk belajar"

Memang dengan pengelolaan kelas yang baik sangatlah menbantu siswa dalam menerima materi pembelajaran di kelas, sebab dengan nyamannya siswa dalam kelas akan berdampak pada semangat dan motivasi belajar siswa, apabila siswa sudah semangat dan termotivasi untuk belajar, maka secara otomatis akan berdampak pada hasil belajar siswa. Hasil wawancara dengan salah seorang guru yakni sebagai berikut:

"Ya memang benar dengan semangatnya siswa dalam belajar, maka akan berdampak positif terhadap hasil belajar, untuk membangkitkan semangat siswa dalam belajar tentunya dengan melakukan pengelolaan kelas dengan baik" 
Memang jika kelas dikelola dengan baik akan berdampak pada semangat siswa dalam belajar, sangatlah penting bagi guru untuk selalu melakukan pengelolaan kelas dengan baik, sehingga dalam melaksanakan proses belajar dan mengajar dapat berlangsung dengan baik dan sesuai dengan harapan.

\section{Prestasi Siswa di Sekolah}

Prestasi siswa di sekolah tidak dapat terlepas dari peran guru dalam melaksanakan tugas pokok dan fungsinya, yaitu mendidik dan mengajar, dalam menjalankan tugasnya guru tentunya professional dalam menjalankan tugasnya seperti mengelola kelas dengan baik. Hasil wawancara dengan kepala sekolah, yakni sebagai berikut:

"Memang sukses dan tidaknya siswa dalam belajar tidak dapat terlepas daru peran guru terutama dalam membuat siswa bersemanagat untuk belajar, siswa bersemangat untuk belajar jikalau guru dapat membuat siswa untuk nyaman dalam belajar, agar siswa nyaman, maka guru harus menciptakan kelas yang baik dan kondusif"

Memang benar prestasi belajar siswa, tidak dapat terlepas dari peran guru dalam menciptakan suasana kelas yang menyenangkan, suasan kelas yang menyenangkan tidak dapat terlepas dari peran guru dalam menciptakan suasana kelas yang menyenangkan, sehingga siswa bersemangat untuk belajar di dalam kelas. Hasil wawancara dengan salah seoarng siswa, yakni sebagai berikut:

"Memang kami akan belajar dengan nyaman tenang dan kondusif jika suasana kelas yang diciptakan guru dalam proses belajar dan mengajar menyenangkan"

\section{Fasilitas Pembelajaran di Sekolah}

Untuk menata kelas dengan baik tidak terlepas dari fasilitas pendukung kelas yang baik pula, agar guru dalam mengelola kelas dapat mengelolanya dengan berbagai variasi sehingga siswa dapat dengan mudah untuk masuk dalam kelas dalam menerima materi pembelajaran. Hasil wawancara dengan kepala sekolah yakni sebagai berikut:

"Saya berusahan semaksimal mungkin untuk memberikan dukungan fasilitas dalam pengelolaan kelas, agar guru dan siswa merasa nyaman dan kondusif dalam melaksanakan proses pembelajaran di dalam kelas"

Fasilitas pendukung sangatlah penting sekali bagi guru dan siswa dalam melaksanakan proses pembelajaran di dalam kelas, apabila fasiliast pendukung cukup banyak, maka guru dapat dengan mudah untuk mengelola kelas dengan baik dan begitu juga siswa dapat dengan mudah untuk belajar karena suasana kelas menyenangkan bagi mereka. Hasil wawancara dengan salah seorang guru, yakni sebagai berikut: 
"Ya fasilitas pendukung sangatlah penting dalam menciptaka suasana kelas yang kondusif, jika fasilitas terpenuhi, maka saya dengan mudah untuk mengelola kelas menjadi lebih baik lagi”"

Fasilitas pendukung sangatlah penting sekali dalam menciptakan suasana kelas yang kondusif, bayangkan jika fasiltas pendukung tidak ada, maka hal ini menjadi masalah besar bagi guru untuk menciptakan suasana kelas yang kondusif, maka dari itu peran kepala sekolah menjadi sangatlah penting dalam mendukung fasilitas yang dibutuhkan bagi guru dan siswa dalam proses belajar dan mengajar.

\section{Menjaga Fasilitas Kelas}

Menjaga fasilitas kelas sangatlah penting agar fasilitas kelas yang ada dapat terpeliharan dengan baik, jika fasilitas kelas yang ada tidak dijaga dengan baik, maka fasilitas akan cepat rusak dan akan menganggu proses pelaksanaan proses belajar dan mengajar. Hasil wawancara dengan kepala sekolah, yakni sebagai berikut:

"Saya sarankan kepada guru dan siswa agar senantiasa menjaga fasilitas

kelas, agar pengelolaan kelas dapat berjalan dengan baik, sehingga selama proses belajar dan mengajar dapat terasa nyaman dan kondusif",

Pengelolaan kelas yang baik tidak dapat terlepas dari fasilitas yang ada, maka dari itu menjadi sangatlah penting, jika dalam pengelolaan kelas fasilitas yang ada dapat terpelihara dengan baik, dengan adanya fasilitas kelas yang baik, maka ruangan kelas yang ada akan menjadi menarik dan siswa akan merasa senang dalam proses belajar dan mengajar. Hasil wawancara dengan salah seorang guru yakni sebagai berikut:

"Saya sangat memelihara fasilitas kelas yang ada, agar dapat terjaga dari kerusakan dan saya menghimbau juga kepada siswa untuk menjaga fasilitas kelas yang baik, sehingga dapat mendukung dalam pengelolaan kelas yang baik pula"

Memang sangatlah penting menjaga fasilitas kelas yang ada, sebab fasilitas kelas sanagat mendukung dalam pengelolaan kelas, jika pengelolaan kelas baik, maka dalam proses belajar dan mengajar akan menjadi baik pula, namun jika tidak, maka akan menganggu dalam pelaksanaan proses belajar dan mengajar.

\section{Meningkatkan prestasi belajar siswa}

Dengan pengelolaan kelas yang baik, maka dapat membantu kenyamanan siswa dalam belajar, jika siswa nyaman dan kondusif dalam belajar, maka siswa akan berkonsentrai dan bersemangat untuk belajar, jika siswa semangat untuk belajar, maka siswa akan merasakan kemudaha untuk belajar dan akan berdampak 
positif terhadap hasil belajar siswa. Hasil wawancara dengan salah seoarang guru, yakni sebagai berikut:

"Iya pengelolaan kelas yang baik dapat membuat suasana kelas menjadi kondusif, jika suasana kelas kondusif maka proses belajar dan mengajar akan menjadi nyaman, sehingga siswa akan bersemangat dalam belajar begitu juga akan bersemnagat dalam menjalankan tugasnya"

Dengan suasana kelas yang nyaman dan kondusif, maka sangatlah membantu siswa dalam proses belajar dna mengajar, siswa akan merasa betah dan enjoy dalam menerima materi pembelajaran dari gurunya, jika suasana kelas kurang nyaman, maka siswa akan resah dan malas untuk belajar sehingga akan berdampak negative terhadap hasil belajar siswa.

\section{Kegiatan Siswa di Kelas}

Untuk menata kelas dengan baik tidak terlepas dari fasilitas pendukung kelas yang baik pula, agar guru dalam mengelola kelas dapat mengelolanya dengan berbagai variasi sehingga siswa dapat dengan mudah untuk masuk dalam kelas dalam menerima materi pembelajaran. Hasil wawancara dengan kepala sekolah yakni sebagai berikut:

"Saya berusahan semaksimal mungkin untuk memberikan dukungan fasilitas dalam pengelolaan kelas, agar guru dan siswa merasa nyaman dan kondusif dalam melaksanakan proses pembelajaran di dalam kelas”

Fasilitas pendukung sangatlah penting sekali bagi guru dan siswa dalam melaksanakan proses pembelajaran di dalam kelas, apabila fasiliast pendukung cukup banyak, maka guru dapat dengan mudah untuk mengelola kelas dengan baik dan begitu juga siswa dapat dengan mudah untuk belajar karena suasana kelas menyenangkan bagi mereka. Hasil wawancara dengan salah seorang guru, yakni sebagai berikut:

"Ya fasilitas pendukung sangatlah penting dalam menciptaka suasana kelas yang kondusif, jika fasilitas terpenuhi, maka saya dengan mudah untuk mengelola kelas menjadi lebih baik lagi”

\section{Faktor Pendukung dan Penghambat Pengelolaan Kelas}

Dalam mengelola kelas tentunya terdapat factor pendukung dan penghambat, sehingga hal ini harus dilewati dan dimanfaatkan oleh guru dengan baik. Hasil wawancara dengan salah seorang guru yakni sebagai berikut:

"Faktor pendukung adalah fasilitas pengelolaan kelas, namun factor penghambat masih ada siswa yang kurang bersemangat untuk belajar, namun hal ini sedikit demi sedikit saya upayakan agar semua siswa bersemnagt untuk belajar" 
Tentu dalam pengelolaan kelas ada tatangan dan hambatan, sehingga hal ini haris diatasi dengan baik oleh guru, agar dalam pengelolaan kelas dapat berjalan dengan baik, namun jika guru tidak mampu mengatasi itu semua, maka pengelolaan kelas tidak dapat berjalan dengan baik.

\section{Faktor penghambat dalam pengelolaan kelas sehingga menjadi kelas yang efektif}

Dalam mengelola kelas tentunya terdapat factor pendukung dan penghambat, sehingga hal ini harus dilewati dan dimanfaatkan oleh guru dengan baik. Hasil wawancara dengan salah seorang guru yakni sebagai berikut:

"Faktor pendukung adalah fasilitas pengelolaan kelas, namun factor penghambat masih ada siswa yang kurang bersemangat untuk belajar, namun hal ini sedikit demi sedikit saya upayakan agar semua siswa bersemnagt untuk belajar"

Tentu dalam pengelolaan kelas ada tatangan dan hambatan, sehingga hal ini haris diatasi dengan baik oleh guru, agar dalam pengelolaan kelas dapat berjalan dengan baik, namun jika guru tidak mampu mengatasi itu semua, maka pengelolaan kelas tidak dapat berjalan dengan baik.

\section{Cara Mengurangi Hambatan dalam Pengelolaan Kelas Sehingga Meningkatkan Prestasi Belajar Siswa}

Untuk menata kelas dengan baik tidak terlepas dari fasilitas pendukung kelas yang baik pula, agar guru dalam mengelola kelas dapat mengelolanya dengan berbagai variasi sehingga siswa dapat dengan mudah untuk masuk dalam kelas dalam menerima materi pembelajaran. Hasil wawancara dengan kepala sekolah yakni sebagai berikut:

"Saya berusahan semaksimal mungkin untuk memberikan dukungan fasilitas dalam pengelolaan kelas, agar guru dan siswa merasa nyaman dan kondusif dalam melaksanakan proses pembelajaran di dalam kelas"

Fasilitas pendukung sangatlah penting sekali bagi guru dan siswa dalam melaksanakan proses pembelajaran di dalam kelas, apabila fasiliast pendukung cukup banyak, maka guru dapat dengan mudah untuk mengelola kelas dengan baik dan begitu juga siswa dapat dengan mudah untuk belajar karena suasana kelas menyenangkan bagi mereka. Hasil wawancara dengan salah seorang guru, yakni sebagai berikut:

"Ya fasilitas pendukung sangatlah penting dalam menciptaka suasana kelas yang kondusif, jika fasilitas terpenuhi, maka saya dengan mudah untuk mengelola kelas menjadi lebih baik lagi”, 
Fasilitas pendukung sangatlah penting sekali dalam menciptakan suasana kelas yang kondusif, bayangkan jika fasiltas pendukung tidak ada, maka hal ini menjadi masalah besar bagi guru untuk menciptakan suasana kelas yang kondusif, maka dari itu peran kepala sekolah menjadi sangatlah penting dalam mendukung fasilitas yang dibutuhkan bagi guru dan siswa dalam proses belajar dan mengajar.

\section{Sumber Masalah yang Menjadi Kendala dalam Menerapkan Model Pengelolaan Kelas}

Dalam mengelola kelas tentunya terdapat factor pendukung dan penghambat, sehingga hal ini harus dilewati dan dimanfaatkan oleh guru dengan baik. Hasil wawancara dengan salah seorang guru yakni sebagai berikut:

"Faktor pendukung adalah fasilitas pengelolaan kelas, namun factor penghambat masih ada siswa yang kurang bersemangat untuk belajar, namun hal ini sedikit demi sedikit saya upayakan agar semua siswa bersemnagt untuk belajar"

Tentu dalam pengelolaan kelas ada tatangan dan hambatan, sehingga hal ini haris diatasi dengan baik oleh guru, agar dalam pengelolaan kelas dapat berjalan dengan baik, namun jika guru tidak mampu mengatasi itu semua, maka pengelolaan kelas tidak dapat berjalan dengan baik.

\section{Rapat atau diskusi tentang permasalahan pengelolaan kelas}

Sangat perlu dilakukan diskusi dan rapat untuk mengelola kelas yang baik, guru harus melakukan komunikasi yang baik antara sejwat dan pimpinan sekolah agar persoalan pengelolaan kelas dapat teratasi dengan baik. Hasil wawancara dengan salah seorang guru, yakni sebagai berikut:

"Ya memang benar saya selalu melakukan diskusi kepada teman sejawat dan pimpinan sekolah dalam hal ini kepala sekolah, sehingga persoalan pengelolaan keas dapat teratasi dengan baik"

Untuk menata kelas dengan baik tidak terlepas dari fasilitas pendukung kelas yang baik pula, agar guru dalam mengelola kelas dapat mengelolanya dengan berbagai variasi sehingga siswa dapat dengan mudah untuk masuk dalam kelas dalam menerima materi pembelajaran. Hasil wawancara dengan kepala sekolah yakni sebagai berikut:

"Saya berusahan semaksimal mungkin untuk memberikan dukungan fasilitas dalam pengelolaan kelas, agar guru dan siswa merasa nyaman dan kondusif dalam melaksanakan proses pembelajaran di dalam kelas"

Fasilitas pendukung sangatlah penting sekali bagi guru dan siswa dalam melaksanakan proses pembelajaran di dalam kelas, apabila fasiliast pendukung cukup banyak, maka guru dapat dengan mudah untuk mengelola kelas dengan 
baik dan begitu juga siswa dapat dengan mudah untuk belajar karena suasana kelas menyenangkan bagi mereka. Hasil wawancara dengan salah seorang guru, yakni sebagai berikut:

"Ya fasilitas pendukung sangatlah penting dalam menciptaka suasana kelas yang kondusif, jika fasilitas terpenuhi, maka saya dengan mudah untuk mengelola kelas menjadi lebih baik lagi”,

Fasilitas pendukung sangatlah penting sekali dalam menciptakan suasana kelas yang kondusif, bayangkan jika fasiltas pendukung tidak ada, maka hal ini menjadi masalah besar bagi guru untuk menciptakan suasana kelas yang kondusif, maka dari itu peran kepala sekolah menjadi sangatlah penting dalam mendukung fasilitas yang dibutuhkan bagi guru dan siswa dalam proses belajar dan mengajar.

Kelas perlu dikelola dengan baik agar dapat mendukung dalam pelaksanaan proses belajar dan mengajar dalam kelas. Untuk mewujudkan manajemen kelas, lingkungan fisik yang menguntungkan dan memenuhi syarat akan mendukung meningkatnya intensitas pembelajaran siswa dan mempunyai pengaruh positif terhadap pencapaian tujuan pengajaran. Manajemen kelas di Sekolah Dasar tidak hanya pengaturan belajar, fasilitas fisik dan rutinitas, tetapi menyiapkan kondisi kelas dan lingkungan sekolah agar tercipta kenyamanan dan suasana belajar yang efektif.

Oleh karena itu, sekolah dan kelas perlu dikelola secara baik, dan menciptakan iklim belajar yang menunjang. Proses belajar mengajar merupakan inti dari proses pendidikan secara keseluruhan dengan guru sebagai pemegang peranan yang utama. Peranan guru adalah menciptakan serangkaian tingkah laku yang saling berkaitan yang dilakukan dalam suatu situasi tertentu serta berhubungan dengan kemajuan perubahan tingkah laku dan perkembangan siswa yang menjadi tujuannya.

Dengan kreatifitas, pengalaman, latar belakang pendidikan guru dan kemampuan guru, maka akan berdampak pada kemampuan guru dalam mengelola kelas dengan baik, hasil penelitian Helsa dan Hendriati (2017) menjelaskan partisipan yang memiliki latar belakang pendidikan guru dan pengalaman kerja yang memadai memiliki kemampuan manajemen kelas yang baik. Sedangkan hasil penelitian Kartiningsih, Asrori, dan Syukri (2014) menjelaskan indikator fungsi manajemen kelas unggulan berupa perencanaan, pengorganisasian, penempatan guru dan pegawai, pendelegasian Kepala Madrasah, Koordinasi Kepala Madrasah, Guru, Pegawai dan Komite, pendanaan, evaluasi program kelas unggulan.

Tugas dan peran guru sebagai pendidik profesional sesungguhnya sangat kompleks,tidak terbatas dalam perencanaan pembelajaran yang menyangkut merumuskan tujuan pembelajaran, materi pembelajaran menetapkan metode pembelajaran, media pembelajaran dan evaluasi untuk mengetahui hasil 
pembelajaran. Namun guru juga harus bisa memainkan perannya dalam pengelolaan kelas, baik yang menyangkut kegiatan mengatur tata ruang kelasyang merupakan; mengatur meja, tempat duduk siswa, menempatka papan tulis, maupunmenciptakan iklim belajar mengajar yang serasi dengan mengarahkan tingkah laku anak didik agar tidak merusak suasana kelas.

Suasana kelas yang kondusif merupakan merupakan modal penting untuk menciptakan kejernihan berpikir untuk mengikuti proses belajar mengajar. Oleh karena itu pengelolaan sekolah perlu menciptakan suasana gembira di sekolah yaitu suasana kekeluargaan yang akrab, dengan demikian guru termotivasi untuk mengelola kelas dengan baik, karena dengan pengelolaan kelas yang baikakan mempertinggi perkembangan mental dan sosial murid, dan memberi kebebasan intelektual dan pasih dalam karakter yang ditentukan, dan membuat suasana yang hangat antara guru dan murid yang memungkinkan pencapaian tujuan terlaksana.

\section{SIMPULAN}

Pengelolaan kelas di SMA Negeri 2 Model Kota Lubuklinggau cukup baik, hal ini dapat dilihat dari suasana kelas dan motivasi siswa dalam belajar cukup baik dan kemudian juga dukungan fasilitas cukup memadai dalam pengelolaan manajemen kelas. Kemudian komunikasi antara teman sejawat dan pimpinan sekolah berjalan dengan baik dalam pengelolaan kelas, sehingga proses belajar dan mengajar di dalam kelas cukup kondusif.

\section{DAFTAR PUSTAKA}

Arikunto, A. (2006). Telaah Pendidikan. Jakarta: Gramedia

Hadari, N. (2002). Organisasi Sekolah dan Pengelolaan Kelas sebagai LembagaPendidikan, Jakarta: Gunung Agung

Helsa, A. (2018). Kemampuan Manajemen Kelas Guru. Jurnal Psikologi Pendidikan, 16(2), 89-104

Kartiningsih, A., \& Syukri, S. (2012). Manajemen Kelas Unggulan di Madrasah. Prodi Magister Administrasi Pendidikan, FKIP, Universitas Tanjungpura Pontianak

Mulyasa, E. (2002). Manajemen Berbasis Sekolah Konsep, Strategi, dan Implementasi,Bandung:PT Remaja Rosdakarya

Novan, A. W. (2013). Manajemen Kelas. Jokjakarta: Ar-Ruzz Media

Sulistyorini, S. (2009). Manajemen Pendidikan Islam. Yogyakarta: TERAS 